\title{
UN CATECISMO Y VARIAS LECTURAS: PODER POLÍTICO Y CATOLICISMO ROMANO EN EL ESPACIO RIOPLATENSE DURANTE LA DÉCADA DE $1850^{1}$
}

\author{
A CATECHISM AND SEVERAL READINGS: \\ ROMAN CATHOLICISM AND POLITICAL POWER \\ IN THE RIVER PLATE AREA DURING THE 1850'S \\ FEDERICO MEDINA •
}

Federico Medina es becario doctoral del CONICET con sede en el CEPIHA, de la Facultad de Humanidades de la Universidad Nacional de Salta.

e-mail: fm0886@gmail.com

\begin{abstract}
Resumen
El presente artículo se ocupa de indagar la recepción que tuvo el catecismo Instrucciones Cristianas del clérigo jujeño Escolástico Zegada entre las autoridades civiles y eclesiásticas del espacio político rioplatense durante la década de 1850 . Este análisis es una puerta de ingreso para comprender las relaciones entre poder político y catolicismo romano así como las tensiones y temores que los cambios producidos por la modernidad liberal despertaron en las jerarquías diocesanas hacia mediados del siglo XIX.
\end{abstract}

\begin{abstract}
This article examines the reception that had the catechism Christian Instructions among the civil and ecclesiastical authorities of the River Plate political area, during the 1850s. This catechism was written by a cleric of Jujuy, Escolástico Zegada. The proposed analysis is a gateway for understanding the relationship between political power and Roman Catholicism as well as the tensions and fears brought by the liberal modernity changes in diocesan hierarchies at midnineteenth century.
\end{abstract}

${ }^{1}$ Este trabajo forma parte de los proyectos de investigación CIUNSa 1893/2 y 1893/3. Agradecemos los valiosos comentarios de los evaluadores de la revista. 